\title{
'BEFORE THE WORLD COLLAPSED BECAUSE OF THE WAR': \\ THE CITY OF FIUME IN THE POETRY OF GIANNI ANGELO GROHOVAZ
}

\author{
KONRAD EISENBICHLER
}

\begin{abstract}
Summary: The article examines how the "native city" is constructed and remembered in the works of the Italian refugee and later emigrant, Gianni Angelo Grohovaz. Born in Fiume (Italy) in 1926, Grohovaz was forced to abandon his city when it was ceded, as spoils of war, to Yugoslavia. After eventually emigrating to Canada, Grohovaz became not only an eloquent voice on behalf of Italian-Canadians, but also a passionate poet for a world and a civilization destroyed, in his view, first by the aftermath of the war and then by Italy's own perfidy towards Fiume and Istria. Though never able to overcome the pain, Grohovaz does eventually reconcile himself with this irreparable loss of a home, a hometown, and a way of life by suggesting that Canada is, in some ways, very much like Fiume and Fiume is, in some ways, very much like Christ.
\end{abstract}

On 8 December 1950, Giovanni Angelo Grohovaz, a 24-year-old Italian from Fiume (today Rijeka, in Croatia), arrived as an immigrant in Canada and disembarked at Halifax's Pier 21.1 Like so many other Italians, he had

${ }^{1}$ Grohovaz, ... e con rispetto parlando, p. 1. The National Archive of Canada has a "John Grohovaz fonds" that contains $1.4 \mathrm{~m}$ of textual records, 566 photographs, 3 audio reels, 1 video reel, and 2 maps. Its biographical sketch on Grohovaz says that: "Gianni Angelo Grohovaz, known as John, was born in 1926 at Fiume, Italy, now Rijeka, Yugoslavia. He was displaced as a result of World War II. In 1947 he was secretary to the association of Refugees from Venezia-Giulia and two years later became block leader with the International Refugee Organization, Naples.

Since his arrival in Canada in 1950, Mr. Grohovaz was an active community member and was co-founder of several organizations including the Catholic Action, the Immigrant Aid Society, the Italian newspaper Il Corriere Canadese, the Italian Orphan Fund and the Italian Veterans Day. After acquiring experience in newspaper publishing with Daisons Publications he served as editor of the Italian weekly Il Giornale di Toronto, 1970-1975. He was the recipient of several poetry awards and the author of a collection of original poems in 
decided to emigrate in the hope of finding a better future abroad. After working in the forests of Northern Ontario on the Canadian National Railroad (CNR), Grohovaz moved to Toronto, married Lisa Paradiso (a young woman from Conversano, in the province of Bari), and began to raise a family. ${ }^{2}$ During his years in Canada, Grohovaz held more than twenty different jobs - after first working for the CNR he then worked at times as an accountant, a translator, carpenter, mechanic, dishwasher, social assistant, administrator, journalist, radio personality, poet, writer and so forth. ${ }^{3}$ In Canada Grohovaz 'was' many things, but most of all he 'was' an Italian, and proudly so-his presence in this country was the direct result not of economic necessity, but of political decisions and nationalistic movements that had obliged him, because he was Italian, to abandon his hometown and emigrate.

This is because Grohovaz was an Italian from Fiume and Fiume was no longer Italian. In fact, at the end of the Second World War, Italy had ceded Fiume as spoils of war to the reconstituted and enlarged Yugoslavia of the Communist dictator Josip Broz-better known by his nom de guerre, Marshall Tito. As a result, Grohovaz and the vast majority of his fellow Fiumani were forced, because they were Italian, to leave everything behind -houses, lands, personal possessions - and move across the new border into Italy. Grohovaz, who was born and raised in Fiume-part of Italy when he was born there in 1926 - saw not only his city, but also the cities of Zara and Pola, the entire peninsula of Istria, and the islands of the Gulf of Quarnero become part of the newly reconstituted and enlarged Yugoslavia. He also saw his fellow Italians living in these new Yugoslavian territories persecuted to the point of night-time arrests, unexplained disappearances, show trials, summary executions, and mass slaughters. The mountain crevices (foibe) in which many of the bodies of Italian victims of

Fiuman dialect entitled Per ricordar le cose che ricordo." See http:// www.archivescanada.ca/english/search ad vocem. Grohovaz died on 14 May 1988 at his summer home in Tiny Township, Ontario. More biographical information on Grohovaz is to be found on the back cover of his novel Strada bianca and in Buranello "Chi mai gavessi deto."

${ }^{2}$ Grohovaz's early years working for the CNR and his meeting with his future wife provide the inspiration for his first book, Strada bianca, a novel written in 1952 but published posthumously in 1989. On this work, see Buranello, "Chi mai gavessi deto" and Cossu, "Lesperienza dell'esule-emigrato."

${ }^{3}$ Buranello, "Chi mai gavessi deto, p. 143. 
Yugoslavian persecution were unceremoniously dumped have now become emblematic of the atrocities and ethnic cleansing carried out by Tito's Communist forces against the Italian population of Venezia Giulia, Istria, Fiume, and Dalmatia. ${ }^{4}$ More than 350,000 Italians from these areas abandoned their homes and moved to Italy because of the closure of the new Yugoslav borders, which now encompassed three entire Italian provinces (those of Zara, Fiume, and Pola) and most of two other provinces (those of Trieste and Gorizia), and because of the physical, economic, political, and psychological persecution they suffered. In the space of a few short years in the mid-1940s, the cities, towns, and villages of Istria and Dalmatia suffered an unprecedented depopulation: Fiume lost 54,000 of its 60,000 inhabitants; Pola 32,000 of its 34,000; Zara 20,000 of its 21,000; Capodistria 14,000 of its 15,000, and Rovigno 8,000 of its $10,000.5$ The same fate befell the smaller towns and villages of the area, to the point that many of them still have not recovered from this demographic collapse and several have been reduced to ghostly ruinsVisignano dropped from 1,746 inhabitants in 1945 to 1,228 in the 1980 s; in the same period Fianona dropped from 300 to 90 , Draguccio from 190 to 70 , Piemonte d'Istria from 168 to 50 , and so on. ${ }^{6}$

Some Italians from these provinces abandoned their cities openly and legally, complete with an official permit from the Yugoslav administration. The majority, however, left their homes clandestinely, without a permit, escaping by day and by night, on foot or by boat, and always at the risk of their lives. When one listens to these refugees talk about their departure

${ }^{4}$ Quite a number of volumes (scholarly studies as well as personal memoirs) have now appeared in Italy detailing the tragic history of Italians from these areas. The most important is Flaminio Rocchi, L'esodo dei 350 mila Giuliani, Fiumani e Dalmati, which has undergone several re-editions and expansions. More recently, the journalist Arrigo Petacco published a very successful general history of this episode, L'esodo. Little or nothing is available in English except for Petacco's work, recently translated as $A$ Tragedy Revealed.

${ }^{5}$ Rocchi, L'esodo, pp. 201-202. See also Buranello, "Considerazioni storiche." Both before, during and after the mass exodus of their original inhabitants, these cities and towns were programmatically repopulated with Slavs from the interior of Yugoslavia; see Petacco, A Tragedy Revealed, for descriptions of these re-population efforts aimed not only at replacing the original inhabitants, but also at refashioning the cities and towns of Istria and Dalmatia into predominantly Slavic centres.

${ }^{6}$ Farina, Itinerari istriani, 18, 75, 161, 202. 
one never hears them speak of a "move" or a "transfer" to Italy, but rather of an "escape" (scampar), or of a "coming out" (venir fora) or a "coming away" (venir via) from Yugoslavia. Their words betray a profound sense of having been forced to escape, of having been pushed to this extreme by fear for their lives or because of direct personal experience with persecution, of having saved themselves and nothing else, of having lost their ancestral homes, their material possessions, their lands, even their way of life. In many cases, there is also a strong sense of having lost their youth. ${ }^{7}$

The loss of one's home, of one's personal and family possessions includes the loss of the home town in all its aspects-from school friends to family tombs, from the local cuisine to the local dialect, from the cultural habits of daily life to the profound sense of thousands of years of history. ${ }^{8}$ This is a historical reality that colours all of Gianni Angelo Grohovaz's poetry, prose, and life. This article will now turn to an examination of Grohovaz's memory of his home town as emblematic of a peaceful and prosperous world destroyed by the ravages of human misunderstanding and violence.

Gianni Angelo Grohovaz's published poetry is limited to a single collection, Per ricordar le cose che ricordo. Poesie in dialeto fiuman, published in Toronto by the Casa Editrice Dufferin in June 1974 and then reprinted two years later in September 1976. Between the two editions, in June

${ }^{7}$ See, for exmple, the poetry of Diego Bastianutti, and especially his collection $\mathrm{La}$ barca in secco where he begins the author's preface with the observation: "Per me, che doverti abbandonare la mia città di Fiume, non ancora adulto e temprato, c'è una particolare amarezza che si aggiunge a quella dell'esilio: quella dell'innocenza che è stata sottratta alla mia infanzia, per aver sofferto dolori di vita già adulta, prima di aver potuto conoscere una breve stagione di spensierata adolescenza" (p. 5); "For me, who had to abandon my city, Fiume, when I was not yet an adult and hardened, there is a particular bitterness added to my exile: that of the innocence that has been taken away from my childhood, because I suffered the pains of a life that was already that of an adult, before I had the chance of knowing a brief season of carefree."

8 Many of the cities and towns of Istria are thousands of years old. While Fiume is a relative newcomer to the area, having been founded in $35 \mathrm{BCE}$ by the Romans, who called it Tarsatica, many other cities in the region were founded by the preRoman Histri population of the peninsula or can claim ancient Greek or Roman pedigrees: Rovigno (Ruginium), Parenzo (Parentium), Pinguente (Piquentum), Pirano (Pyrrhanum), Umago (Sepomagum), Albona, Fianona (Flanona), etc. 
1976, the collection won the Primo Premio Speciale at the fourth annual European Literary Competition "Premio San Benedetto" sponsored by the Academic Association "Amici dell'Umbria." The author, however, was not able to travel to Norcia to receive the prize (he sent his mother, instead) because at that time he was busy in Toronto with the inauguration of the monument to the Alpini "wished for, designed, created, and built by him" ("da lui voludo, disegnado, creado, e costruito"; 1976, p. 2) in the park behind the Columbus Centre and next to the Villa Colombo retirement home (26 June 1976). Remembering this moment, Grohovaz is keen to point out not only the honour bestowed upon him by the Umbrian association and his mother's pleasure in going to Norcia to receive it on his behalf, but also the fact that inside the monument to the Alpini there is "a small vial that contains the soil of Saint Vitus" ("una fialeta che contien Tera de San Vito"; 1976, p. 2); that is, soil from Fiume (together with Saints Modestus and Crescentia, Saint Vitus is the patron saint of Fiume). Immediately after this revelation, Grohovaz explains that the vial is "a small thought for all those Fiumani who served the Homeland in the Alpine corps" ("un piccolo pensier per tutti quei Fiumani che ga servì la Patria soto la naja alpina"; 1976, p. 2). The presence of Fiume in Grohovaz's poetic imagination is therefore indicated not only generically by the collection's subtitle - that emphasizes the Fiuman dialect of the poems-but also by the many poems that speak of Fiume. All of this is heightened by the touching revelation that Grohovaz included a vial of soil from Fiume inside the monument to the Alpini, as if the monument were a reliquary. This is very appropriate, for the Fiume Grohovaz remembers is, like the Alpini the monument honours, a casualty of war, a life sacrificed for Italy. The remnants of that life, represented by the small vial of soil from Fiume, are therefore relics to be treasured and honoured.

In fact, throughout the poetry the predominant image of Fiume is sacrificial and martyrological. In Grohovaz's imagination, Fiume is soon refashioned along Christological lines. The title of the prefatory paragraph to the second edition (1976, p. 2) already suggests this Christology"ROBE DE CIODI" (A MATTER OF NAILS—upper case in the original). The allusion to the nails of the Cross and, by extension, to the Passion of Jesus, is undeniable-like Jesus, Fiume has been nailed to a cross and sacrificed for a higher cause.

${ }^{9}$ Grohovaz, Per ricordar le cose che ricordo, 1976, p. 2. Future references to Grohovaz's collection will be incorporated into the text; when the date is not given, the reference will be to both the 1974 and 1976 edition, interchangeably. 
The Christological imagery, however, is not new: it was already present in the first edition of the book, where it appeared in the title of the second poem in the collection "E ti Fiume, povero Cristo ...." (And you, Fiume, a poor Christ ...; p. 19). In this poem Grohovaz explicitly likens the martyrdom of his home town to the Passion of Jesus. Right under the title, and set off by parentheses, the poet added a stage direction: the sound of a hammer is heard beating on nails (") se sente un rumor de martel che bate ciodi)")- - a reference not so much to the Crucifixion (Jesus hanging on the cross) as to the nailing (Jesus being nailed to the cross), that is, to one of the initial moments of Jesus' execution. In line with Grohovaz's stage direction, the poem is to be read or recited with the sound of a hammer beating time in the background:

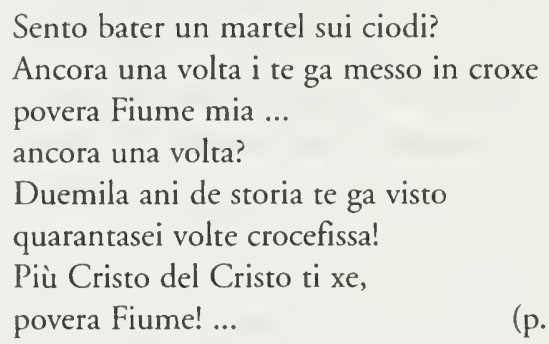

(Do I hear a hammer beating on nails? / Once again have they crucified you / My poor Fiume ... / Once again? / Two thousand years of history have seen you / Crucified forty-six times! / You are more Christ than Christ,/ Poor Fiume! ...)

In these opening verses the punctuation is significant. The two question marks suggest the incredible nature of what is happening; the two exclamation marks confirm the harsh reality of this latest martyrdom; the two ellipses reveal the author's despair in the face of his unfortunate city's fate. After this opening in the triple key of surprise, shock, and despair, the poet continues with a description of the Passion of Fiume, a victim of so many traitors and so many deniers:

tanti Giuda, tanti Caini
tanti pitori che con un colpo de pinel
i zerca de nasconder
i tuoi Natai

(so many Judases, so many Cains / so many painters who with a brushstroke I seek to hide / your origins).

With the deniers Grohovaz introduces an interesting poetic twist: after 
the traitors Judas and Cain one would have expected the denier Peter to make an appearance, but, instead, Grohovaz changes metaphor and introduces the image of painters who whitewash reality-an allusion to the many Communist and Slavic slogans painted by Tito's supporters on the houses of Fiume and to the Yugoslav re-writing of history to suggest that Fiume or Istria were always Slavic. ${ }^{10}$

Every good Passion, however, ends with the Resurrection. And so Grohovaz concludes his lament for Fiume and his Christological imagery with a strong affirmation of an eventual resurrection: just as Christ rose, so will Fiume also rise again ("così come ga fato el Cristo / Fiume risorgerà ancora"). In the last verses the poet speaks directly to his city and comforts it with the words:

Più Cristo del Cristo ti xe,
povera Fiume mia ...
dopo el Calvario
ti sorgerà su ancora ..."

("You are more of a Christ than Christ / my poor Fiume ... / After your Calvary / You will rise once again ...")

Grohovaz closes with a second stage direction, again in parentheses: the bells of Fiume are heard ringing ("(se sente a sonar le campane de Fiume)"; p. 22), an allusion to the peal of bells that announces the resurrection of Christ on Easter Sunday morning.

The Christological imagery in the poetry is echoed in two strategically placed drawings included in the two editions of the collection. On page 5 of the first edition (June 1974), immediately following the frontispiece drawing of Fiume's clock tower (p. 3), there is a rough pen sketch of Jesus hanging on the cross with an almond-shaped aureole around him and rays

${ }^{10}$ An excellent example of such nationalistic revisionism is the current Croatian appropriation of non-Croatian figures such as Marco Polo (whom they claim is Marko Pilič, a Croatian from the island of Curzola) or the sixteenth-century humanist and philosopher Francesco Patrizi da Cherso (whom they claim as Frane Petrič, born in what is now Cres, Croatia). The same has been done with cities: a bronze plaque on the external north wall of the Duomo in Ossero (Osor) claims that, after the town "was founded by the Illyrian tribe called the Liburians at the beginning of the first century B.C.," it was "under the rule of the Roman Empire from the first century A.D.", and then "under the rule of" Byzantium, Venice, Napoleon, Austria, and Italy until, finally, "on April 20th 1945 the town of Osor was incorporated into the mother country Croatia" (emphasis added). 


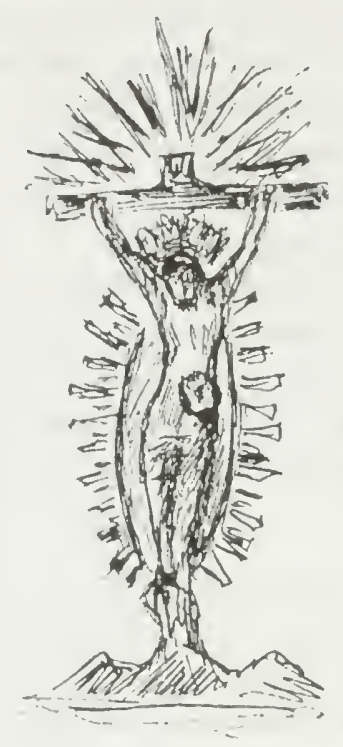

11 firni den fimmani. nati in giro per el mondo dopo el tragico ribalton (d) 19.5 .5$.

Ahrora una volfa due mondi se gaveva roto i comi tra de lori: uno ga

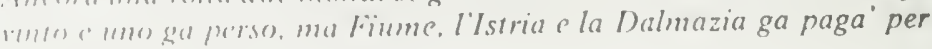
IIIII).

Fig. 1 Grohovaz, Per ricordar le cose che ricordo (1974), p. 5, with Maria Ivis Superina's drawing of the Crucified Christ and Grohovaz's dedication "Ai fioi dei fiumani" signed "jag". of light emanating upward from the crossbeam of the cross (fig. 1). ${ }^{11}$ In the

${ }^{11}$ The illustration is not signed, but it is probably by Maria (Uccia) Ivis Superina who signs some of the illustrations and whom Grohovaz thanks in the volume for the design of the cover and the drawings; Grohovaz, Per ricordar le cose che ricordo, p. 9. Uccia Superina was born in Pola in 1925 and died in Toronto on 31 March 2005. Aside from her interest in drawing, she was also a frequent correspondent to L'Arena di Pola (the monthly newspaper of the exile community from Pola currently published in Trieste), where she was remembered twice by Irma Sandri Ubizzo in two short notes, "Incontri" (25 Feb. 2005), p. 5 and "Ricordo di Uccia” (30 April 2005), p. 10. 


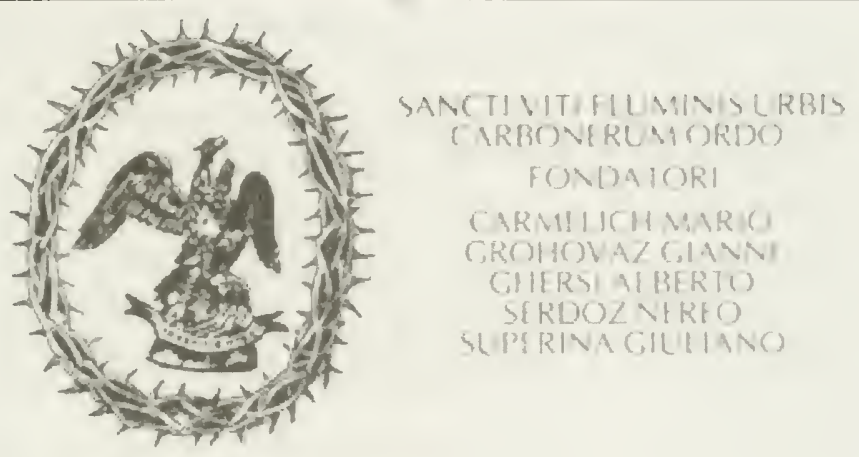

II NESTGCIO DES CARRONIERI

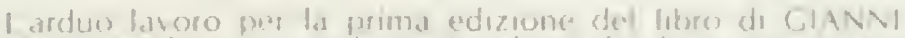

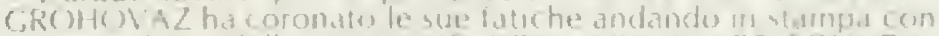
un comeributo de lle URLINC COMMUNII) ART FOLNDATIOA di TORONIO - (ANADA o if dismerenater labse den

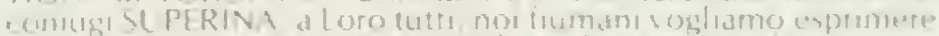
if ir onose mentes ber if meravighoses lavor iompacio

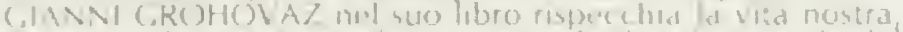

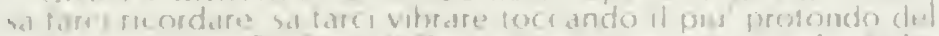
memero intame CROHC)

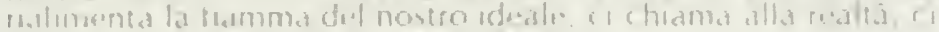

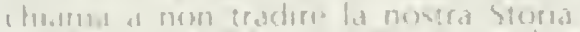

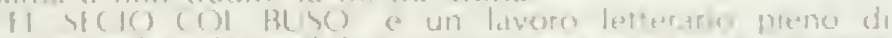

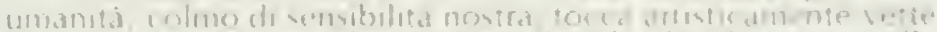

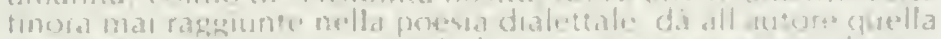

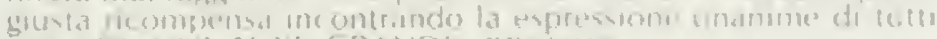

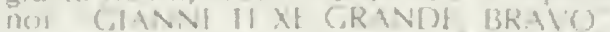

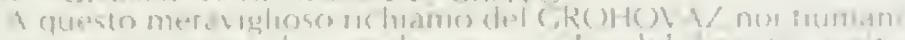

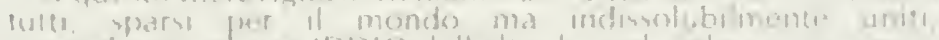

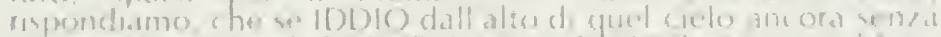

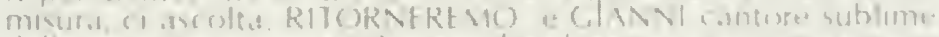

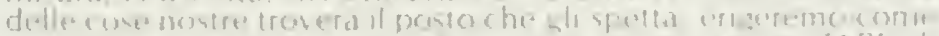

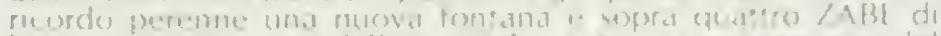

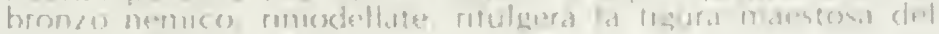

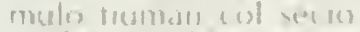

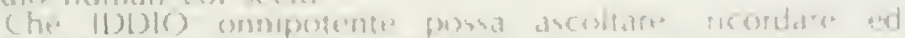

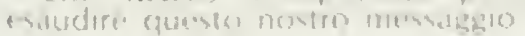

MARIO)( ARSHHICH

Fig. 2 Grohovaz, Per ricordar le cose che ricordo (1976), p. 3, with Maria Ivis Superina's drawing of the Fiuman eagle in a crown of thorns and Mario Carmelich's "Il messaggio dei Carbonieri".

second edition (September 1976), the drawing of the clock tower on p. 3 has been replaced by a "Message from the Carbonieri" signed by a certain Mario Carmelich; at the top of the "Message" there is a rather unusual symbol (again, a drawing): the Fiuman eagle, with spread wings and standing with one talon on a rock and the other on a reclining amphora with water pouring from it, is enclosed or framed by a crown of thorns (fig. 2). The reference to the Passion is unmistakeable. 
This is, however, a somewhat unusual Fiuman eagle. First, it has clearly been decapitated of one of its two heads. The normally double-headed eagle is missing its left or "eastern" head. This is not an oversight or something that should pass unnoticed. The stump of the long left neck is clearly visible and commands the viewer's attention. This demi-decapitated eagle is a clear reference to Fiume's Dannunzian period (1919-20) when its two-headed eagle fell victim to Gabriele D'Annunzio's legionnaires who cut off its left head in an attempt to signal the end of the eagle's and the city's Habsburg past. ${ }^{12}$

In spite of an obvious irredentist interpretation, this strange portrayal of a demi-decapitated Fiuman eagle framed by a crown of thorns perhaps should be seen as nothing more than an innocuous fantasy on the part of five Fiuman exiles then living in Toronto who, in the mid 1970s, were in the habit of gathering together for the pleasure of their company and to remember their youth in Fiume. According to Grohovaz, the group called itself "Carbonari [The Union of Carbonari of Fiume]" ("carboneri [Flumentium Unitas Carbonerum Ordendorum]"; p. 22); according to Mario Carmelich, instead, they called themselves "The Order of Carbonari of St Vitus' City of Fiume" ( "Carbonieri [...] Sancti Viti Fluminis Urbis Carbonerum Ordo"; 1976, p. 3; see fig. 2). ${ }^{13}$ Considering the grandiose, if not pompous name of the Order, the bad Latin in both Grohovaz's and Carmelich's rendition of the group's name, the praises Carmelich bestows

${ }^{12}$ The double-headed eagle was given as an emblem to the city on 6 June 1659 by Emperor Leopold I von Habsburg. Before that date, the city's emblem had been its patron Saint Vitus. "The new emblem presented a damasked light blue background, framed in gold, a crimson red crest with a two-headed eagle in the middle (unlike the Austrian imperial eagle, the Fiuman eagle turned both its heads in a single direction, to the left), surmounted by the archducal crown and resting on a rock cliff with its right leg, while with the claws in its left leg it held a vase with water running out of it. Under the crest there was [a cartoon with] the word "Indeficienter" [unfailing] that probably referred not to the water that ran inexhaustibly from the vase, but to the Fiumani's faithfulness to the House of Austria." (translated from the web site of the Centro di Documentazione Multimediale, Trieste, at http://www.arcipelagoadriatico.it/storfiu_IIIsez4.htm) ${ }^{13}$ The five men are Mario Carmelich, Gianni Angelo Grohovaz, Alberto Ghersi, Nereo Serdoz, and Giuliano Superina. The Carbonari were secret groups of Italian patriots who, in the first half of the nineteenth century, worked to free Italy from foreign domination (primarily in the Austrian-controlled regions of Lombardy and Veneto) and pushed for a united and independent Italian state. Their ideals were revolutionary and, politically, liberal. 
on behalf of the carbonieri on one of the more scatological poems in the collection ("El secio col buso", pp. 37-40) we can safely conclude that we are not witnessing an instance of Fiuman carboneria and Italian irredentism, but rather an innocuous fantasy on the part of five middle-aged expatriates reminiscing about their schooldays and imagining themselves to be a "revolutionary" cell of "patriots." In fact, Grohovaz himself recalls that the Carboneri were "a small group of Fiumani in Toronto" that had met the previous 15 June 1973 to celebrate their city's patron saints (p. 22).14 In spite of Grohovaz's affirmation that he wanted to remind "those hard of hearing" that Fiume was an Italian city and that the true Fiumani were now dispersed throughout the world ("Go scrito sta poesia per ricordarghe ai duri de orecia che Fiume xe italiana anche se i fiumani veri i xe tutti in giro per el mondo"; p. 22), the group may have been more goliardic than subversive in inspiration and more of a parody of past Italian underground movements than a peril to the new post-war order in Yugoslavia. ${ }^{15}$

No one would expect otherwise from the gruff Grohovaz, who did not hesitate to voice his opinions bluntly or to chastise authority whenever he deemed it necessary, as can easily be seen in his collection of radio monologues, ... e con rispetto parlando. Although he was firmly Italian in his mind and culture, Grohovaz was not prepared to resort to arms to "Italianize" Fiume- the fact was that the Fiume Grohovaz remembered and cherished was not a pure laine Italian city in need of redemption and union with the "homeland" (as the Irredentisti would want it to be), but a multi-ethnic, multi-lingual, multi-cultural city whose various races, languages, and cultures cohabited peacefully with one another. The poet describes this peaceful cohabitation in a poem inspired by the memory of his three pets: his dog, his cat, and his canary. The work is entitled "Amor de bestie, odio de cristiani" ("The Love of Animals, The Hatred of People"):

Giulieto, el canarin de casa nostra, col can e 'l gato andava assai d'acordo:

14“El 15 de giugno 1973, I CARBONERI [Flumentium Unitas Carbonerum Ordendorum], [un grupeto de Fiumani a Toronto], se riuniva per celebrar i Santi Protetori de Fiume, Vito e Modesto, così come vol la tradizion." (Grohovaz, Per ricordar le cose che ricordo, p. 22; upper case in the original)

${ }^{15}$ I should add that in the blank space after the last poem in the collection, there is a pen drawing of the crest of Fiume with a single-headed eagle and, above it, a crown of city walls. Its Habsburg connections (the two heads and the archducal crown) have completely disappeared from this rendition of the crest. 
el Grom dormiva soto al fogoler

la gata ghe lavava anca le orece mentre l'usel el se fazeva el nido tra le pieghe de la pele in testa al can ...

Mia mama ghe butava le zeriese:

l'usel becava un poco, e poi el lassava

che la gata ghe dassi una lecada.

El can, ciapava la zeriesa,

la mastigava un poco, e spudà l'osso

tornava pacifico a dormir ...

E noi cristiani ... non capimo un'acca:

che le zeriese, spartirsele bisogna!

Perché le flicche, ${ }^{16} \mathrm{i}$ bori ${ }^{17}$ e le agiateze

non poderemo portarse drio domani

quando el becchin se spuderà le mani

per meter soto tera i nostri ossi.

(Giulieto, the canary at our house / With the dog and cat got along well: / Grom would sleep under the fireplace / The cat would even wash his ears / While the bird made a nest for himself / Among the folds on the dog's head ... / My mom would throw a few cherries at them: / The bird picked at them a bit, and then let / The cat give them a lick. / The dog would grab the cherry, / Chew it a bit and, having spat out the pit, / Would go back, peacefully, to sleep ... / And we, human beings ... ${ }^{18}$ don't understand anything: / Cherries are meant to be shared! / Because the pennies, money, and easy living / We won't be able to take with us tomorrow / When the gravedigger will spit on his hands / Before putting our bones into the ground.)

The ethnic and cultural peace that reigned in Fiume 'before the world collapsed because of the war' ("prima ch'el mondo crolasse per la guera," p. 93) was based, according to Grohovaz, on peaceful cohabitation. In the poem, the dog Grom represents the Austro-Hungarians in Fiume's population, the nameless cat represents the Slavs, and the bird Giulieto the Italians, and the three live comfortably together, sharing their food and their daily lives. Grohovaz calls the poem a fiaba (fable), but then quickly

16"flica n. fem., a coin worth twenty cents; by extension, money; for ex. "El xe pien de fliche. A lu no ghe manca le fliche." Samani, Dizionario, p. 68.

17 "bori $n$. masc. pl., money. "I Michetic ga fato i bori co i vini dalmati. Chi ga bori, ga tuto. E via lu co i bori de 'l ojo" (i.e., he left without paying). Samani, Dizionario, pp. 35-36.

${ }^{18}$ In dialect, cristian is used to indicate a human being (though, admittedly, it does generally refer to a European stock, or "civilized" human being). 
affirms it to be true and takes it to be a lesson 'for us people who do not know how to love each other and too often forget that life is really short: from here to there and no more' ("per noi cristiani che non savemo volerse ben e troppo spesso se dimentichemo che la vita la xe veramente curta: da quà fin là e non de più.” p. 85).

Politics, according to Grohovaz, is what complicates life and destroys social peace. In the preface to the collection Grohovaz thinks back to the Fiume of his youth and exclaims: "What beautiful times. What a place was our Fiume" ("Che bei tempi. Che tera che iera la nostra Fiume." p. 11) and then identifies the cornerstone for this idyllic peace:

Me ricordo che bastava non parlar de politica [maledeta politica, diria el mio Zio Miro] e tuto filava come l'ojo. Ebrei, zifuti, cristiani, turchi, morlacchi e meneghei de altretante nazionalità passava da le nostre parti e poi i se fermava perché l'America del monopatino la jera proprio la, in quela feta de tera tra due mondi dove tuto se podeva meter a posto davanti a una piadina de fasoi col lardo e un litro de quel bon. Bastava no parlar de politica. (p. 11)

(I remember that it was sufficient not to speak of politics [damned politics, my Uncle Miro would say] and everything ran as smooth as oil. Jews, Hebs, Christians, Turks, Morlacchi, and Johnnies from just as many other nationalities would pass by our town and then stop there because the America of the scooter was, in fact, right there, in that slice of land between two worlds where everything could be set right in front of a bowl of beans with lard and a litre of good wine. All you had to do was not talk politics.)

Even border disputes with near-by Susak (the town on the other side of the river Eneo that marked the border between Italy and the Kingdom of Yugoslavia) were resolved amicably with a meeting between the two mayors and an exchange of foodstuffs:

El Podestà che passa, se ricorda, che dopopranzo ariva i dignitari de la vizina Sussak per discuter el tropo contrabando de frontiera. [...]

La Tore bate altri due colpi sordi el Podestà tracana el suo "pelin" e rinfrancado el va xo in Municipio per ordinar l'uscier in Punto Franco a prelevar del zucaro e café (de solito maniera assai eloquente) per render ragionevole la gente ... 
$[\ldots]$

El Podestà già spera dentro a sè

ch'el Sindaco de Sussak porti in cambio

persutto afumicado e vin de Bosnia

e forsi 'na botiglia de rakia ...

(The Mayor who walks by remembers / That after lunch the dignitaries / From near-by Susak will arrive to discuss / The excessive smuggling across the border. / [...] The Clock Tower rings out another two muffled strokes / The Mayor throws back his "pelinkovač" / And, refreshed, goes to City Hall / To send his doorman to the Duty Free / To get some sugar and coffee / (Usually a very eloquent way / To convince people to be reasonable ...) / [...] The Mayor already hopes within himself / That the Mayor of Susak might bring in exchange / Some smoked prosciutto and Bosnian wine / And perhaps a bottle of rakia ... ${ }^{19}$

Unfortunately, the idyllic peace and convivial fellowship that reigned in this multicultural and apolitical Fiume did not last. It was swept away by a storm. The bufera, which gives its name to the first poem in the collection, is not so much the Second World War, as the post-war period or, more precisely, the sequence of invasions, occupations, confusions, and violence that followed the armistice of 8 September 1943.20 Grohovaz begins the poem with a description of the German forces that arrive in Fiume, the retreat of the Italian forces, the threatening proximity of Tito's Yugoslav Communist forces, and the internal hatreds and violence that suddenly erupted in Fiume:

Quando pareva che tuto era finido, (dopo la firma l'oto de setembre), a Fiume nove gnochi xe arivadi e con un panzer i ne ga "liberà". L'esercito italiano in bancarota i sumari ${ }^{21}$ del bosco già a Cantrida ${ }^{22}$

e noi sgomenti e in piena confusion guardavimo la fine, el ribalton ...

${ }^{19}$ Pelinkovač is a Croatian or Serbian curative liqueur made from wormwood. Rakia is a Yugoslavian brandy made from distilled fruits; its most common form, Slivovitz, is made from distilled prunes.

${ }^{20}$ For a description of this turbulent post-Armistice period, see Petacco, A Tragedy Revealed. pp. 36-108.

${ }^{21}$ A person from the woods (from the Croatian suma meaning "woods").

${ }^{22}$ Neighbourhood in Fiume just west of the industrial area. 
Bombe pioveva quel autuno a Fiume jera s'ciopada una grossa al Bonavia 23 nissun capiva un'acca, e mularia coi s'ciopi abandonadi i se copava! Povera Fiume: tra due foghi stavi come una cogoma de cafe bojente ... I gnochi de una parte, e jera zente che i se giurava: "l'Austria xe tornà"! Dall'altra parte i slavi ne voleva per via dell'odio vecio e per el porto.

L'Italia era lontana, e se vedeva che due, de Italie ne saria restà ... Non jera più ragion de far la guera: jera la pele, jera, e l'odio seminà in cesa, a casa, a scola e sul lavoro: perfin le babe odiava in Braida ${ }^{24}$ sul mercà ... (pp. 15-16)

(When it seemed that everything was finished, / After the signing on 8 September, / Nine krauts arrived in Fiume / And "freed" us with a Panzer. / The Italian army was in shatters, / The hillbillies were already in the woods at Cantrida / And we in anguish and completely confused / Were looking at the end, at the overthrow ... / Bombs were raining that autumn in Fiume / A large one had exploded at the Bonavia Hotel / No-one understood anything, and children / With abandoned guns were killing each other! / Poor Fiume: you stood between two fires / Like a pot of boiling coffee ... / The krauts on one side, and there were people / Who swore: "Austria has returned"! / On the other side the Slavs had it against us / Because of the old hatred and of our port. / Italy was far away, and one could see / That there was going to be two Italies ... / There was no reason any more for waging war: / There was [the need to save one's] skin, there was, and hatred sown / At church, at home, at school and at work: / Even the women at the market in Braida hated ...)

The poem, a hundred verses long, ends with the bitter realisation that Fiume suffered more after than during the war; that is, that once the war was over and Fiume was ceded to Marshall Tito's Yugoslavia the city lost more people than during the entire war-and here the poet is clearly referring not to the casualties of war, but to the depopulation of the city caused by the exodus of $85 \%$ of its population. ${ }^{25}$ One of these exiles was Grohovaz

23 Luxury four-star hotel in Fiume, still in business.

${ }^{24}$ Neighbourhood at the eastern edge of Fiume developed at the turn of the twentieth century by the Triestinian architect Giacomo Zammattio. Previously the area had either been left as open fields or cultivated with vineyards.

25 "The second largest mass exodus, after that of Zara, took place in Fiume. Even 
himself - a fact he now regrets. Once established in Canada, Grohovaz notes:

Quà son che scrivo, e non so darme paze

per el rimorso e la vigliacheria

per el nostro grande sbaglio de 'ndar via

e de lassarte, o Fiume, al tuo destin ...

(Here I am, writing this, and I cannot find any peace / Because of regret and cowardice / Because of our great mistake in going away / And leaving you, $\mathrm{O}$ Fiume, to your fate ...)

Grohovaz blames himself and, by extension, all other Fiumani who, in fleeing to save their lives, abandoned Fiume to her tragic destiny. Instead of staying and guaranteeing, with their presence, the survival of what Fiume was, the exiles allowed this haven of multiculturalism strategically located between Eastern and Western Europe to fall apart and disappear. In the prose comment at the end of this opening poem Grohovaz notes that war is bad for everyone, "and especially for those who die in it," but what is more tragic is having to decide what to do in order to live with one's conscience and then not knowing what to do (p. 19).

This may be the dilemma that explains, at least in part, the reason for the ambiguity Grohovaz feels towards Italy as a state. Although he was more than ready to help his fellow Italian refugees in the five and a half years he spent in the refugee camp at Bagnoli, near Naples, and although in Toronto he assisted the local Italian community (see above, n. 1), at the same time Grohovaz distanced himself from "official" Italy. The final blow was struck by the Treaty of Osimo which Italy signed with Yugoslavia in 1975 and by which it ceded the so-called "Zona B" to Yugoslavia. This was a section of Istria immediately to the south of Trieste, comprising the cities

though at first a large number of the working class and petit bourgeoisie of Fiume might have thought of possibly getting along with the new regime, after the long months of terror and serious economic crisis there was solid disagreement with the Yugoslav communists. In the end, about $85 \%$ of the population abandoned Fiume. According to the estimates published by the Opera per l'Assistenza ai Profughi Giuliani e Dalmati, between 1946 and 1947 more than 25,000 Italians left Fiume. Before that time, another 6-7,000 Italians had already left the city. The phases of the exodus from Fiume can be divided into two major periods: the first in 1945 and the second after the signing of the Peace Treaty in 1947. In Istria, instead, the phenomenon was more protracted. In this manner, the city of Fiume was emptied of its Italian element." Translated from the Centro di Documentazione Multimediale, Trieste, web site at http://www.arcipelagoadriatico.it/framestorfiu.htm 
of Capodistria, Pirano, Umago, Cittanova, Buie, and the territory around them. Acceptance of the terms of the treaty constituted official recognition of the loss of all Italian territories on the eastern shores of the Adriatic. After the treaty an irate Grohovaz inveighed against Italy. In the poem "Io ti ripago: Italia senza core" (I pay you back, heartless Italy), which he added to the 1976 edition (pp. 4-5), Grohovaz accuses Italy of being "'shopkeeper' / timid, renunciatory, and 'drop your pants'" ("'boteghera', / pavida, rinunciatrice e 'calabraghe"; p. 4) exactly because "without blushing for shame / you have ceded my land to Tito. / Beautiful Istria, Italian and mine / has become a thing to be bartered with ..." ("senza arrossire di vergogna / hai ceduto la mia terra a Tito. / L'Istria bella, italiana e mia / è diventata oggetto di baratto ..." p. 4). ${ }^{26}$ If Italy can give so much of itself as a gift to Tito, then, Grohovaz concludes, he too can do the same and he sends the Communist dictator two things very dear to him: the Gold Medal for Military Valour earned by his grandfather "on the Carso, on the Piave and at Caporetto, / at Santa Goriza, on the mountains and down in the trenches" ("Sul Carso, sul Piave e a Caporetto, / a Santa Gorizia, sui monti e giù in trincea"; 1976, p. 5) when he had fought to unite Italy and his grandfather's Knighthood Cross - two honours "that for my Grandfather meant the world" ("che per mio Nonno volean dir tutto"; 1976, p. 5). According to Grohovaz, his poor grandfather was a duped man (ingannato) because he had believed that Italy was sincera (honest, truthful, sincere); but Grohovaz has "a laugh about it, / bitter, if you want, but a laugh" ("una risata, / amara se vuoi, ma una risata"; 1976, p. 5). He signs the comment with the lower case initials "jag" that stand for John Angelo Grohovaz-no longer Gianni or Giovanni, or Nini, but John.

The anglicized signature actually precedes this great disappointmentit appears on p. 5 of the 1974 edition after his comment below the drawing of Jesus on the cross. It is not to be seen so much as a refusal of Italy (though it may be so in part), as a prise de conscience that here, in Canada, he has become a new person. In fact, Grohovaz signs the preface to his volume with the phrase "here they call me / John Angelo Grohovaz" ("qua i me ciama / John Angelo Grohovaz"; p. 11), as if to say that here he is someone else-no longer the "Nini del Monte" as he was called in Fiume (p.

26 The poem is not part of the 1974 collection (for obvious reasons, since it is inspired by the 1975 Treaty of Osimo); it is inserted into the 1976 collection at pp. 4-5, that is, on what had been the blank verso of the page with Maria Ivis Superina's drawing of the bell tower of Fiume (replaced in 1976 with "Il Messaggio dei Carbonieri") and the page with the drawing of the crucified Jesus with the aureole (1974, p. 5). 
10). In spite of his being another person in Canada and of his ambivalence that sometimes has him signing as Gianni, Giovanni, John, or jag, what is clear is that, in the end, he is and remains a Fiumano. And, as such, he feels completely at home in Canada because, after all, Canada and Fiume are very similar.

In the poem "Chi mai gavessi deto? Fiume e Canadà ..." (Who ever would have said it? Fiume and Canada ...), Grohovaz recalls how, as a child in Fiume, he used to play "at being Canadian", that is, at cops and robbers. As he explains it, the "Canadian" was the Mountie "who always brought the scoundrel to jail" ("quel .... (non me ricordo el nome): / un tipo bravo, che su "L'Aventuroso" / portava sempre in cheba el malandrin"; p. 31). In spite of the children's game, for he and his schoolmates Canada was a very distant land, so much so that the page in the atlas with Canada on it was always as fresh as new because it was never consulted. The young Grohovaz never thought that one day he himself would go to Canada as an immigrant. However, as he explains in the poem, the defeat of Italy and its "drop your pants" nature forced him to go wandering in the world. Now he finds himself in Canada where, much to his surprise, he notes that this new country shares many similarities with his Fiume. Grohovaz admires Canadian multiculturalism and notes that it is very easy for a Fiumano to live in Canada "because here, too, there are all types of people: / all races, a hundred religions, / seventy-five languages (and opinions)" ("perché anca quà xe zente de ogni sorte: / tute le raze, cento religion, / setantazinque lingue (e opinion)"; pp. 31-33). In the prose comment that follows the poem Grohovaz observes:

Non so se sia un pregio opur un difeto, fato sta che tra el Canada e Fiume xe qualche cossa che fila come l'ojo. Guarde' el nostro dialeto, pien de parole ciolte in prestito da: taliani, ungaresi, slavi, francesi, turchi e gnochi. Cussì come jera a Fiume, chi vien in Canada vien qua per restar. Ma se domani Fiume me ciamassi ... (p. 33)

(I don't know if it's a good or a bad thing, but the fact is that between Canada and Fiume there is something that runs as smooth as oil. Look at our dialect, full of words borrowed from: Italians, Hungarians, Slavs, French, Turks, Krauts. Just as in Fiume, those who come to Canada come here to stay. But if tomorrow Fiume were to call me ...)

If Fiume were to call him, what would Grohovaz do? Would he return? In the preface written in the summer of 1987 to his novel Strada bianca (The White Road), composed in 1952 but published posthumously in 1989, Grohovaz observed: 
Il Canadà è grande, e come Fiume diventerà multiculturale in un pluralismo cònsono ed incredibilmente ricco. [...] Non c’è Paese al mondo che possa vantare un passo più lento, ma più certo e più sicuro verso un progresso che non ha rivali. Dio salvi e protegga questo Paese! No, non v'è ragione per ritornare sui mei passi. Solo Fiume ... ma il Signore è in tutt'altre faccende affacendato.. .27

(Canada is large, and like Fiume it will become multicultural in a pluralism that is harmonious and incredibly rich [...] There is no country in the world that can claim to move more slowly, but more certainly and more surely towards a progress that has no rivals. God save and protect this country! No, there is no reason to retrace my steps. Only Fiume ... but the Lord is busy with completely different matters ...)

For Italian immigrants from Italy, it is very easy to return to their hometowns. For Italians from Fiume (or from Istria or Dalmatia), who were forced to abandon their hometowns for political reasons and who have then seen them gutted and refashioned in a Slavic nationalistic keywho have seen Fiume become Rijeka, the Piazza Dante become Trg Republike Hrvatske, the Teatro Municipale Giuseppe Verdi become the Hrvatsko Narodno Kazalište Ivana pl. Zajca, the Italian dialect one heard while strolling along the Corso become Croatian-for them a return to their native town is impossible. Their only alternative, as Grohovaz acknowledges in the poem "Ritorno col pensiero" is to return to the hometown in one's thoughts. And so, in an imaginary sea voyage from Venice to Fiume, Grohovaz "rows, challenges the gulf, cuts the waves / returns by sea to the lost shores!" ("voga, sfida el golfo, taja l'onda / torna per mar a la perduta sponda!"; p. 29). He reaches the shores of Istria, rounds Capo Promontore, slides past the coast of Laurana "with its intense aroma ("dal profumo intenso"), of Abazia "Queen of the Quarnero" ("regina del Quarner"), of Volosca and Preluca and arrives, at last, at Fiume where, like a prodigal son tired from his exile and of the tasteless bread of foreign lands (an obvious allusion to Dante), he kisses his native soil and brings to it as a gift "all the bitterness of my vile exile!" ("tuto l'amaro del mio esilio infame!" p. 30). This bitterness, born from the realization that he has been betrayed like a poor Christ and from seeing himself, in turn, betrayed like a poor Judas, conditions and colours the poetics of memory and the remembrance of Fiume in the works of Gianni Angelo Grohovaz.

Victoria College

University of Toronto

${ }^{27}$ Grohovaz, Strada bianca, 3. 


\section{Works Cited}

Bastianutti, Diego. La barca in secco, ill. by Susan Paloschi, introductory essay by Sergio Maria Gilardino. Ottawa: Legas, 1995.

Buranello, Robert. "Chi mai gavessi deto: The Immigrant Experience in Giovanni Angelo Grohovaz's Strada bianca" in An Italian Region in Canada. The Case of Friuli-Venezia Giulia, edited with an introduction by Konrad Eisenbichler. Toronto: Multicultural History Society of Ontario, 1998, pp. 137-152.

Buranello, Robert. "Considerazioni storiche e prospettive moderne sui GiulianoDalmati canadesi." Italian Canadiana 9 (1993): 46-59.

Cossu, Francesco. "L'esperienza dell'esule-emigrato nel romanzo di Giovanni A. Grohovaz Strada bianca." Fiume Anno 26, n.s. 13.1 (2006): 163-168.

Farina, Romano. Itinerari istriani. Sensazioni ed immagini. Biblioteca istriana, 10. Trieste: Edizioni Italo Svevo, 1989.

Grohovaz, Gianni Angelo. Per ricordar le cose che ricordo. Poesie in dialeto Fiuman. Toronto: Casa Editrice Dufferin, 1974; 2nd ed. 1976.

Grohovaz, Gianni Angelo. ... e con rispetto parlando è al microfono gianni grohovaz. Diario radiofonico, quasi settimanale, di un italiano in Canada, 1980 1981 - 1982. 74 editoriali radiotrasmessi dalla CHIN, stazione radio internazionale di Toronto, Ontario, Canada. Toronto: La Casa Editrice Sono Me, 1983.

Grohovaz, Gianni Angelo. Strada bianca. Dall'estrema sponda dell'Adriatico alle diecimila cattedrali dell'Ontario. Toronto: La Casa Editrice Sono Me, 1989.

Petacco, Arrigo. L'esodo. La tragedia negata degli italiani d'Istria, Dalmazia e Venezia Giulia. Milan: Arnoldo Mondadori, 1999.

Petacco, Arrigo. A Tragedy Revealed. The Story of the Italian Population from Istria, Dalmatia, and Venezia Giulia, 1943-1956, trans. Konrad Eisenbichler. Toronto: University of Toronto Press, 2005.

Rocchi, Flaminio. L'esodo dei 350 mila Giuliani, Fiumani e Dalmati. 4th ed. Rome: Ediz. Difesa Adriatica, 1998

Samani, Salvatore. Dizionario del dialetto fiumano. A cura dell'Associazione Studi sul Dialetto di Fiume. Venice and Rome: s.n., 1978.

Electronic Sources

http://www.archivescanada.ca http://www.arcipelagoadriatico.it http://www.cain-rcia.ca 